\title{
Altered Serum Lipids in the Cases of Head and Neck Cancer Associated with the Habit of Tobacco Consumption
}

\author{
Setty L. N. Chandra Mohan, D. Satyanarayana \\ Department of Otolaryngology and Head and Neck Surgery, Mahatma Gandhi Memorial Hospital Warangal, Telangana, India \\ Email: drsettylnchandramohan@gmail.com
}

How to cite this paper: Mohan, S.L.N.C. and Satyanarayana, D. (2017) Altered Serum Lipids in the Cases of Head and Neck Cancer Associated with the Habit of Tobacco Consumption. International Journal of Otolaryngology and Head \& Neck Surgery, 6, 28-37.

https://doi.org/10.4236/ijohns.2017.63006

Received: March 26, 2017

Accepted: May 28, 2017

Published: May 31, 2017

Copyright $\odot 2017$ by authors and Scientific Research Publishing Inc. This work is licensed under the Creative Commons Attribution International License (CC BY 4.0).

http://creativecommons.org/licenses/by/4.0/

(c) (i) Open Access

\begin{abstract}
Alterations in serum lipid profile patterns have long been associated with malignancies, and their role remains controversial with respect to head and neck cancer. Due to an increased rate of neoplastic cell multiplication and reduced supply, there is increased utilization of lipids causing Hypolipidemia. Adding to this, tobacco contains carcinogens capable of damaging the cell membrane components including lipids resulting in further hypolipidemia. Thus the purpose of the present case control study is to discuss the alterations in plasma lipid profile in head and neck cancer patients in association with tobacco consumption. This hospital based study includes 80 cases of head and neck cancer patients and 50 controls. Plasma Lipids included are total cholesterol (TC), high density lipoprotein cholesterol (HDL), low density lipoprotein cholesterol (LDL), very low density lipoprotein cholesterol (LDL), triglycerides (TG). Student's "t test" was applied to the data acquired. Values of $\mathrm{P}<$ 0.05 were considered significant and $\mathrm{P}>0.05$ were considered statistically insignificant.
\end{abstract}

\section{Keywords}

Lipids, Cholesterol, Triglycerides, Head and Neck Cancer

\section{Introduction}

Lipids are the main cell membrane components that are essential for various biological functions. Cholesterol is an extremely important biological lipid molecule involved in the synthesis of a number of essential vitamins, steroid hormones and bile acids. The cellular requirement of cholesterol is satisfied from two sources: exogenously from receptor mediated uptake of low-density lipoproteins and endogenously from mevalonate. The mevalonate pathway is a sequence of 
enzymatic reactions (Figure 1) leading to Farnesyl pyrophosphate, which is the common substrate for the biosynthesis of cholesterol and isoprenoid compounds. Mevalonic acid having an essential role in DNA replication raised the possibility that a derangement in mevalonate synthesis might play a role in carcinogenesis [1]. Since 1980, a number of studies have revealed that there is a loss of cholesterol feedback control in cancer cells. This loss of the cholesterol feedback control leads to uncontrolled synthesis of mevalonate causing damaged DNA synthesis and uncontrolled hypocholestrelemia. Lipids are associated with cancer because they play an important role in cancer cellular integrity [2] [3] Lipids are useful for the study of variation in Cholesterol levels in many diseases.

It has been found that altered Serum Cholesterol levels are associated with breast and colorectal cancers [4] [5] [6]. Head and neck cancer is one of the leading causes of mortality and morbidity in India. Globally, it's the $6^{\text {th }}$ most common cancer in the world [7]. Tobacco is the most important etiological agent in head and neck cancer. There are 72 measurable carcinogens in tobacco and are classified as Group I carcinogens by IARC [8].The most important players in tobacco causing head and neck cancer are 4-Nitroquinilone-1-oxide (NQO) and Dimethylbenzanthracene (DMBA) [9]. The carcinogen in tobacco stimulates free radicals and reactive oxygen species release which in turn cause increase in Peroxidation and Oxidation of Polyunsaturated fatty acids. Due to enhanced lipid peroxidation, there is a greater consumption of lipids including total cholesterol, triglycerides, and lipoproteins for the synthesis of new cell membranes. To meet the voracious requirement, there is an increased metabolism of

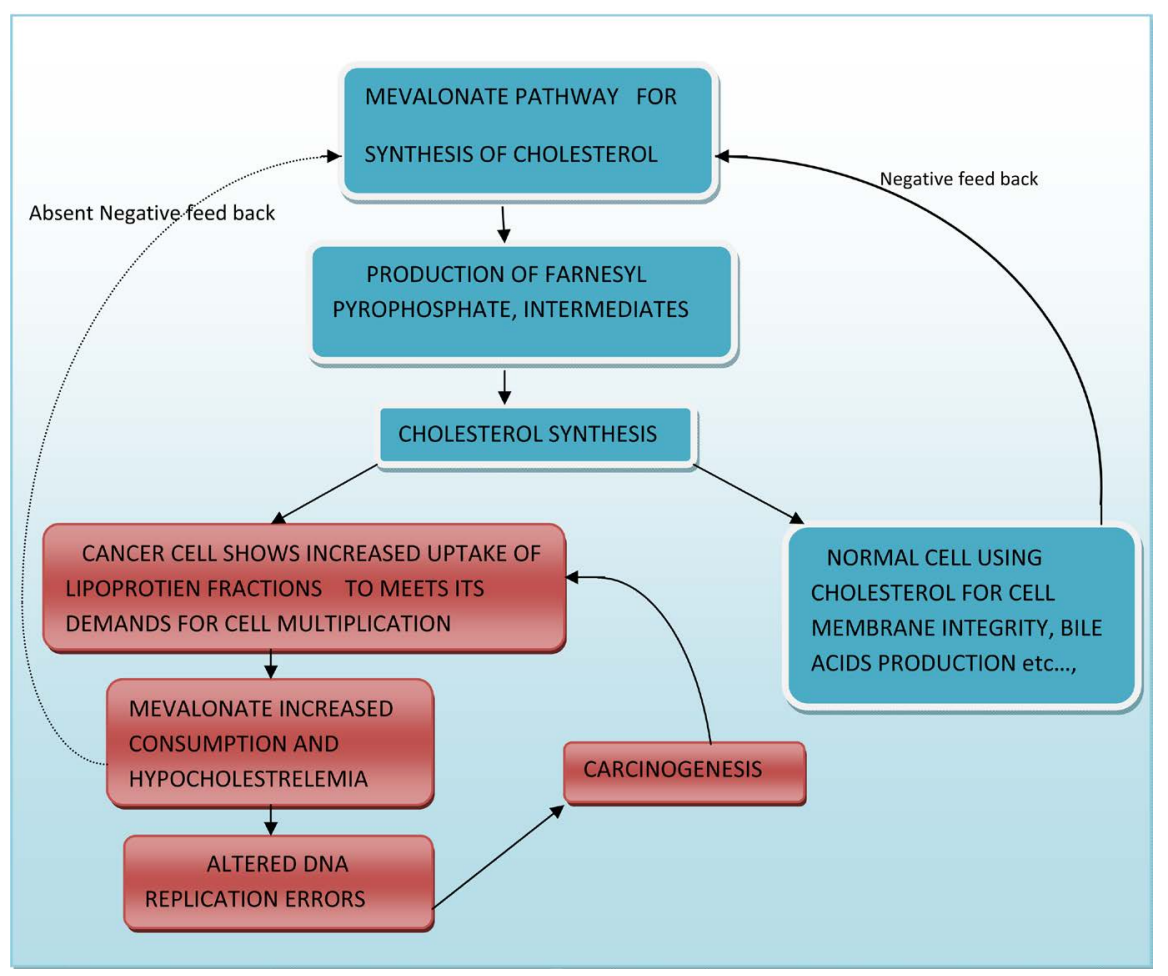

Figure 1. Mevalonate pathway in normal cells and an altered pathway in cancer cells leading to carcinogenesis and Hypocholestrelemia. 
lipoprotein fractions such as VLDL, LDL, and HDL. The present study is aimed to evaluate the Plasma lipid profile (including total cholesterol (TC), high density lipoprotein cholesterol (HDL), low density lipoprotein cholesterol (LDL), very low density lipoprotein cholesterol (LDL), triglycerides (TG)) in head and neck cancer patients.

\section{Materials and Methods}

The following study was conducted in Department of Otolaryngology and Head and Neck surgery at Mahatma Gandhi Memorial Hospital, Warangal during a span of 1 year from January 2016 to January 2017. A total of 80 patients were taken into the study and 50 subjects acted as controls. The controls were selected from the relatives of the patients who accompanied them. The case taken into account were diagnosed both clinically and histo pathologically. All the cases taken into this study had well differentiated Squamous cell carcinoma.

Staging of the cases was done as per AJCC Classification 2009 ( $7^{\text {th }}$ edition). 28 cases of Stage I, 34 cases of Stage II, 8 cases of Stage III, 8 cases of Stage IV, were included in this study. The patients diagnosed with Head and Neck cancer were having Oral cancer $(\mathrm{n}=34)$, Oropharyngeal cancer $(\mathrm{n}=6)$, Hypopharyngeal cancer $(n=8)$, Laryngeal cancer $(n=24)$, Thyroid cancer $(n=6)$, Unknown primary $(\mathrm{n}=2)$. All the above data is represented in Table 1 .

\section{Criteria for Cases Selection}

\section{Study Inclusion Criteria}

1) Individuals with habit of smoking tobacco and chewing tobacco.

2) Individuals who were diagnosed clinically and histopathologically with Cancer.

3) Patients age 25 and above.

4) Patients with an Unknown primary, with a histological diagnosis, in form of wedge biopsy/Fine Needle Aspiration Cytology (FNAC).

\section{Study Exclusion Criteria}

1) Individuals suffering from other diseases that might alter the lipid levels (Hypothyroidism, Hyperthyroidism, Nephritic syndrome, Malabsorbtion, Adrenal Insufficiency, Marfan Syndrome, Hematological diseases, Liver diseases).

2) Patients who have habit of Tobacco consumption in any form.

3) Patients with History of Head and Neck cancer or treated cancer.

4) Patients with Benign head and neck tumors.

5) Patients having skin cancer.

6) Patients with Lymphomas, Haematological Cancers, Tuberculosis.

7) Patient with history of/diagnosed with HIV/AIDS/Tuberculosis and receiving Anti Tuberculosis treatment/Treatment for HIV.

8) Patients receiving Hypolipidemia drugs or drugs causing Hypolipidemia were excluded. 
Table 1. Clinicopathalogical details of the cases and controls in the study.

\begin{tabular}{|c|c|}
\hline Age of Cases & 48 \\
\hline Median & $26-71$ \\
\hline \multicolumn{2}{|l|}{ Range } \\
\hline \multicolumn{2}{|l|}{ Age of Controls } \\
\hline Median & 55 \\
\hline Range & $37-72$ \\
\hline \multicolumn{2}{|l|}{ Gender of Cases $(n=80)$} \\
\hline Male & $62(77.518 \%)$ \\
\hline Female & $18(22.5 \%)$ \\
\hline \multicolumn{2}{|l|}{ Gender of Controls $(n=50)$} \\
\hline Males & $46(92 \%)$ \\
\hline Females & $4(8 \%)$ \\
\hline \multicolumn{2}{|l|}{ Site } \\
\hline Oral Cavity cancer & $34(42.5 \%)$ \\
\hline Oro Pharynx cancer & $6(7.5 \%)$ \\
\hline Hypopharyngeal cancer & $8(10 \%)$ \\
\hline Laryngeal cancer & $24(30 \%)$ \\
\hline Thyroid cancer & $6(7.5 \%)$ \\
\hline Unknown Primary & $2(2.5 \%)$ \\
\hline \multicolumn{2}{|l|}{ Stage } \\
\hline I & $28(35 \%)$ \\
\hline II & $34(42.5 \%)$ \\
\hline III & $8(10 \%)$ \\
\hline IV & $8(10 \%)$ \\
\hline \multicolumn{2}{|l|}{ T Stage } \\
\hline $\mathrm{T} 1$ & $28(35 \%)$ \\
\hline $\mathrm{T} 2$ & $26(32.5 \%)$ \\
\hline $\mathrm{T} 3$ & $16(20 \%)$ \\
\hline $\mathrm{T} 4$ & $8(10 \%)$ \\
\hline \multicolumn{2}{|l|}{ Nodal status } \\
\hline $\mathrm{N}^{+}$ & $38(47.5 \%)$ \\
\hline $\mathrm{N}^{-}$ & $42(52.5 \%)$ \\
\hline \multicolumn{2}{|l|}{ Cancer in females $(n=16)$} \\
\hline Oral Cavity cancer & $8(10 \%)$ \\
\hline Oro Pharynx cancer & $2(2.5 \%)$ \\
\hline Laryngeal cancer & $2(2.5 \%)$ \\
\hline Thyroid cancer & $4(5 \%)$ \\
\hline \multicolumn{2}{|l|}{ Cancer in males $(n=64)$} \\
\hline Oral Cavity cancer & $26(32.5 \%)$ \\
\hline Oro Pharynx cancer & $4(5 \%)$ \\
\hline Hypopharyngeal cancer & $8(10 \%)$ \\
\hline Laryngeal cancer & $22(27.5 \%)$ \\
\hline Thyroid cancer & $2(2.5 \%)$ \\
\hline Unknown Primary & $2(2.5 \%)$ \\
\hline \multicolumn{2}{|c|}{ Smoking Tobacco habit in Females } \\
\hline$>10$ years & $5(625 \%)$ \\
\hline$>20$ years & $\begin{array}{l}5(6.25 \%) \\
7(8.75 \%)\end{array}$ \\
\hline \multicolumn{2}{|c|}{ Smoking Tobacco habit in males } \\
\hline$>10$ years & $18(22.5 \%)$ \\
\hline$>20$ years & $34(42.5 \%)$ \\
\hline \multicolumn{2}{|l|}{ Female smoking habits } \\
\hline Tobacco smoking & $12(15 \%)$ \\
\hline Chewing tobacco & $8(10 \%)$ \\
\hline \multicolumn{2}{|l|}{ Male Tobacco habits } \\
\hline Tobacco smoking & $48(60 \%)$ \\
\hline Tobacco chewing & $10(12.5 \%)$ \\
\hline
\end{tabular}




\section{Blood Sample Collection}

Fasting serum lipid profile was obtained from both Cases and Controls who were placed on fasting for a minimum of 12 hours prior to obtaining the blood samples. The blood samples were collected at least two times to evaluate the lipid changes in patients. The samples were allowed to clot and the serum obtained was centrifuged in an Automated Alere Cholesterol LDX analyzer.

\section{Habit of Tobacco Consumption in the Subjects}

Habit of tobacco consumption in one or the other form of smoking tobacco/chewing tobacco/chewing lime/chewing Areca nut is highly prevalent in India. In our study, $97.5 \%$ of the patients with Head and Neck cancer were consuming tobacco in one form or other. The association of cancer of oral cavity and tobacco was $42.5 \%$.The details regarding habit of tobacco consumption in association with head and neck cancer are provided in Figure 2. Tobacco chewing form of readily available pouch (Gutka) and/or with lime was common in the patients with Oral cancer and Oropharyngeal cancer. A combination of Bidi and Gutka was more commonly seen in Oral cavity cancer and in the female subjects the habit of Tobacco chewing along with Areca Nut was more commonly seen. Tobacco smoking for more than 10 years was seen in 23 cases $(28.75 \%)$ and smoking for more than 20 years was seen in 41 cases (51.25).

\section{Results}

A Significant decrease in Serum Total Cholesterol $(\mathrm{P}<0.001)$, HDL $(\mathrm{P}<0.001)$, LDL $(\mathrm{P}<0.001)$, in Head and Neck cancer patients when compared to Controls. Our results strengthen the evidence of an Inverse relation existing between Serum Lipid levels and Cancer. Table 2 depicts the data recorded from the cases and controls. Table 3 shows that significant P values in Stage I, II, III, and IV in TC, HDL, and LDL. Non significant value of $\mathrm{P}$ was noted in Stage I, III, IV of VLDL, and TG. The total cholesterol in males and female with cancer in comparison to controls is depicted in Figure 3.

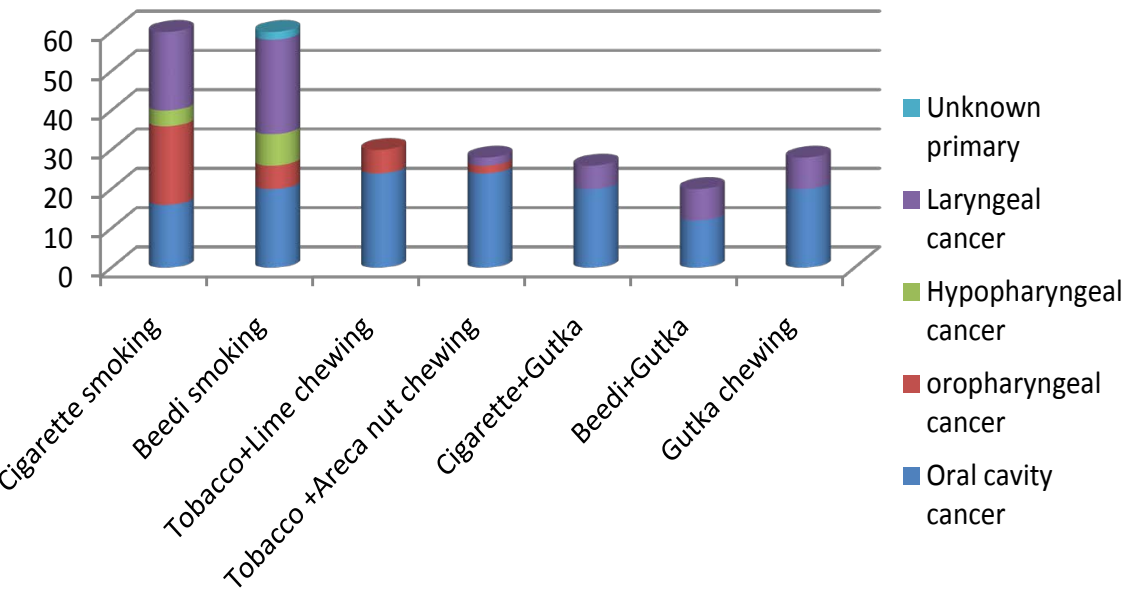

Figure 2. Showing tobacco consumption in various forms in Head and Neck cancer patients. 




Figure 3. Comparing total cholesterol in cancer in males, female and controls.

Table 2. Comparing lipid profile in cases and controls.

\begin{tabular}{cccccc}
\hline \multicolumn{2}{c}{ CASES } & \multicolumn{2}{c}{ CONTROLS } & P Value \\
\hline Variables & Mean \pm SD & Range & Mean \pm SD & Range & \\
TC & $146.8 \pm 26.8$ & $212-84$ & $187.1 \pm 11.3$ & $210-149$ & $<0.001^{*}$ \\
HDL & $47.6 \pm 12.1$ & $84-27$ & $63.8 \pm 5.4$ & $72-50$ & $<0.001^{*}$ \\
LDL & $70.9 \pm 11.1$ & $118-27$ & $92.8 \pm 13.8$ & $113-51$ & $<0.001^{*}$ \\
VLDL & $28.5 \pm 11.1$ & $56-14$ & $30.1 \pm 2,5$ & $34.6-21.8$ & 0.4321 \\
TG & $141.4 \pm 54.4$ & $252-70$ & $151.1 \pm 13.2$ & $173-109$ & 0.3179
\end{tabular}

${ }^{*} \mathrm{P}<0.05$ is significant.

Table 3. Comparing mean lipid value and $\mathrm{P}$ value in different stages of cancer.

\begin{tabular}{ccccccccc}
\hline & \multicolumn{2}{c}{ Stage I } & \multicolumn{2}{c}{ Stage II } & \multicolumn{2}{c}{ Stage III } & \multicolumn{2}{c}{ Stage IV } \\
\hline Variables & Mean \pm SD & P value & Mean \pm SD & P value & Mean \pm SD & P value & Mean \pm SD & P value \\
TC & $138 \pm 27.8$ & $<0.001^{*}$ & $153.6 \pm 25.1$ & $<0.001^{*}$ & $148 \pm 27.9$ & $<0.001^{*}$ & $171 \pm 28.2$ & $0.033^{*}$ \\
HDL & $45.3 \pm 13.3$ & $<0.001^{*}$ & $46.5 \pm 11.6$ & $<0.001^{*}$ & $47.1 \pm 7.52$ & $<0.001^{*}$ & $48.1 \pm 13.3$ & $<0.001^{*}$ \\
LDL & $65.4 \pm 24.6$ & $<0.001^{*}$ & $74.3 \pm 20.9$ & $0.0011^{*}$ & $67.8 \pm 29.6$ & $0.0011^{*}$ & $80 \pm 24.9$ & $<0.001^{*}$ \\
VLDL & $28.6 \pm 15.7$ & 0.56 & $25.8 \pm 6.94$ & $\underline{0.0028^{*}}$ & $31.5 \pm 8.23$ & 0.46 & $32 \pm 13.6$ & 0.48 \\
TG & $150 \pm 78.1$ & 0.94 & $125 \pm 28.2$ & $\underline{0.0001^{*}}$ & $162 \pm 36.6$ & 0.16 & $160 \pm 66$ & 0.47 \\
\hline${ }^{*}<<0.05$ is significant & & & & & & &
\end{tabular}

\section{Conclusion}

Our study reveals that there is a significant reduction in Lipid parameters (TC, HDL, LDL) in cancer patients. The study also reveals Stage II cancer showing Significant reduction in VLDL and TG. Hence in depth study is necessary involving larger populations to confirm this finding.

\section{Discussion}

The majority of the Cholesterol in the body is in the cell membrane structure 
while the rest of it is in blood. Sphingolipids and cholesterol form rafts that move within the cell membrane bilayer. These rafts function as platforms for the attachment of proteins when membranes are moved around inside the cell and during signal transduction [10]. Cholesterol plays important part in membrane trafficking assembly of signaling complexes on the plasma membrane. The Cholesterol presenting in blood is in constant transit between blood and tissue, carried in form of four major Lipoproteins namely HDL, LDL, VLDL, IDL. The normal human body derives energy from break down of free fatty acids and lipoprotein. On the other hand the cancer cell requires a high amount of metabolic intermediates in form of proteins, nucleic acids and lipids, a prerequisite for rapid proliferation [11]. HDL transports cholesterol from peripheral tissue to liver thereby prevents accumulation within tissue. The cancer cell accumulates a large cholesterol intracellularly for its rapid cell growth and division resulting in decreased cholesterol efflux from cancer cell and thus resulting in reduced HDL cholesterol [12]. Cancer cells show De novo Lipogenesis [13] to meet their increased requirement but even then this won't be sufficient for oncogenic signaling and its cell membrane synthesis, leading it to derive this from exogenous fatty acids. The oncogenic signals include ceramide-1-phosphate, platelet activating factor, diacylglycerol and lysophosphatidic acid [14] [15] [16]. The De novo lipogenesis in cancer cells causes increase in Monosaturated fatty acids which protect the cancer cell from oxidative killing and also chemotherapeutic agents [13]. Furthermore all cases in our study had habit of tobacco consumption in one form or other. Carcinogens in tobacco are responsible for increase in peroxide free radical production due to oxidation/peroxidation of Poly unsaturated free fatty acids [17]. This results in further consumption in lipids adding to already decreased plasma lipids.

In 1974, Rose et al. [18] reported that serum cholesterol was found lower in cancer colon patients, followed by Kark et al. [19] reporting low cholesterol levels in lung cancer patients. Following these discoveries many researchers found Hypolipedimia in several cancers though alterations were seen with respect to LDL, VLDL, TG, reduced levels of HDL seen in most of the studies. Schatzkin et al. [2] and Chyou et al. [20] observed an inverse trend between lower serum cholesterol in head and neck cancer as well as in esophageal cancers. The lower serum lipid status may be considered a useful indicator for initial changes occurring in the neoplastic cells. In the study done by Omoti et al. the mean serum cholesterol \& LDL in the cancer patients were significantly lower than those of controls [21]. In one study done at The Edith Wolfson Medical Centre in, Israel they found that the LDL levels showed that a $1 \mathrm{mg} / \mathrm{dl}$ increase in LDL was accompanied by a relative $2.4 \%$ and $2.5 \%$ reduction in odds of hematological cancer and fever/ sepsis respectively [22]. This leads to the question if there can be a value so significant that we can determine the prognosis of a patient by the lipid values. Aexopoulos et al. [23] had found non-significant difference in serum triglycerides between cases and controls. Study done by Nydegger et al. revealed that serum 


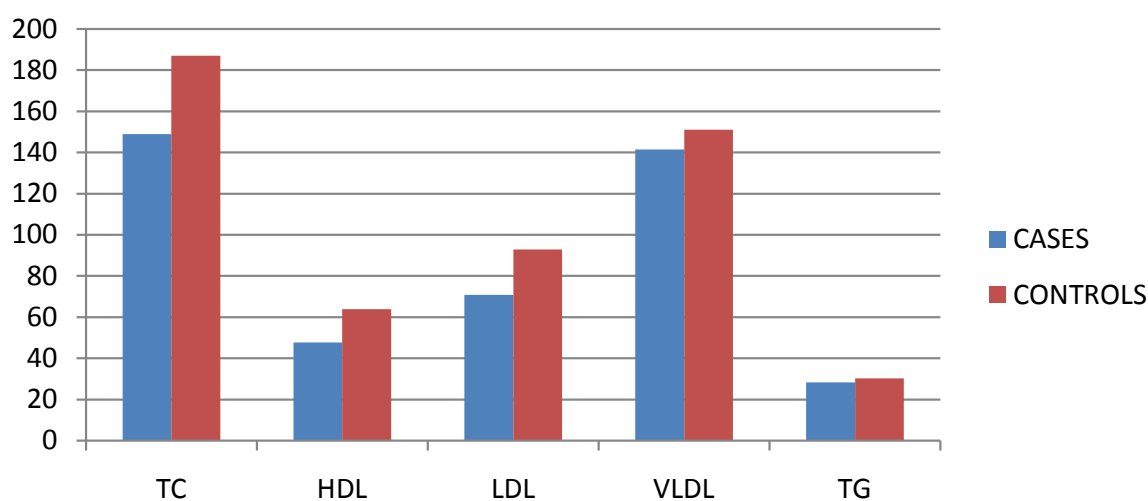

Figure 4. Comparing the lipid parameters between cases and controls.

triglycerides and cholesterol levels were markedly decreased in cancer patients [24].

Figure 4 depicts the different lipid parameters comparing cases and controls. It shows that there is significant difference between cases and controls with respect to TC, HDL, and LDL. In our study we noted that though the mean levels of VLDL, TG in the cases were lower compared to controls, they weren't significant. However values of VLDL, TG in Stage II cancer shows significant $P$ value. Hence to correlate with our findings an in depth study is necessary to find out the changes in lipid levels per stage of cancer by involving a larger populations based study.

\section{References}

[1] Huneeus, V.Q., Wiley, M.H. and Siperstein, M.D. (1980) Isopentenyl Adenine as a Mediator of Mevalonate-Regulated DNA Replication. Transactions of the Association of American Physicians, 93, 347-356.

[2] Schatzkin, A., Hoover, R.N., Taylor, P.R., Ziegler, R.G., Carter, C.L., Albanes, D., et al. (1988) Site-Specific Analysis of Total Serum Cholesterol and Incident Cancers in the National Health and Nutrition Examination Survey I Epidemiologic Follow-Up Study. Cancer Research, 48, 452-458.

[3] Halton, J.M., Nazir, D.J., McQueen, M.J. and Barr, R.D. (1998) Blood Lipid Profiles in Children with Acute Lymphoblastic Leukemia. Cancer, 83, 379-384. https://doi.org/10.1002/(SICI)1097-0142(19980715)83:2<379::AID-CNCR24>3.0.C $\mathrm{O} ; 2-\mathrm{P}$

[4] Gerber, M., Richardson, S., DePaulet, P.C., Pujol, H. and DePaulet, A.C. (1989) Relationship between Vitamin E and Polyunsaturated Fatty Acids in Breast Cancer: Nutritional and Metabolic Aspects. Cancer, 64, 2347-2353. https://doi.org/10.1002/1097-0142(19891201)64:11<2347::AID-CNCR2820641126> 3.0.CO;2-V

[5] Gerber, M., Cavallo, F., Marubini, E., Richardson, S., Barbieri, A., Capitelli, E., et al. (1988) Liposoluble Vitamins and Lipid Parameters in Breast Cancer. A Joint Study in Northern Italy and Southern France. International Journal of Cancer, 42, 489494.

[6] Forones, N.M., Falcan, J.B., Mattos, D. and Barone, B. (1998) Cholesterolemia in Colorectal Cancer. Hepatogastroenterology, 45 1531-1534. 
[7] Paul, L., Kruger, E. and Tennant, M. (2010) Oral Cancer in Western Australia, 1982-2006: A Retrospective Epidemiological Study. Journal of Oral Pathology \& Medicine, 39, 376-381.

[8] International Agency for Research on Cancer (2004) Tobacco Smoke and Involuntary Smoking. Vol. 83, International Agency for Research on Cancer, Lyon, World health organization.

[9] Steele, V.E. and Lubet, R.A. (2010) The Use of Animal Models for Cancer Chemoprevention Drug Development. Seminars in Oncology, 37, 327-338. https://doi.org/10.1053/j.seminoncol.2010.05.010

[10] Simons, K. and Gerl, M.J. (2010) Revitalizing Membrane Rafts: New Tools and Insights. Nature Reviews Molecular Cell Biology, 11, 688-699. https://doi.org/10.1038/nrm2977

[11] Feinleib, M. (1983) Review of Epidemiological Evidence for a Possible Relationship between Hypocholesterolemia and Cancer. Cancer Research, 43, 2503S-2507S.

[12] Mandal, C.C. and Rahman, M.M. (2014) Targeting Intracellular Cholesterol Is a Novel Therapeutic Strategy for Cancer Treatment. Journal of Cancer Science and Therapy, 6, 510-513.

[13] Rysman, E., Brusselmans, K., Scheys, K., Timmermans, L., Derua, R., Munck, S., Van Veldhoven, P.P., Waltregny, D., Daniëls, V.W., Machiels, J., Vanderhoydonc, F., Smans, K., Waelkens, E., Verhoeven, G. and Swinnen, J.V. (2010) De Novo Lipogenesis Protects Cancer Cells from Free Radicals and Chemotherapeutics by Promoting Membrane Lipid Saturation. Cancer Research, 70, 8117-8126. https://doi.org/10.1158/0008-5472.CAN-09-3871

[14] Wymann, M.P. and Schneiter, R. (2008) Lipid Signaling in Disease. Nature Reviews Molecular Cell Biology, 9, 162-176. https://doi.org/10.1038/nrm2335

[15] Arana, L., Gangoiti, P., Ouro, A., Trueba, M. and Gomez-Munoz, A. (2010) Ceramide and Ceramide-1-Phosphate in Health and Disease. Lipids in Health and Disease, 9, 15. https://doi.org/10.1186/1476-511X-9-15

[16] Tsoupras, A.B., Iatrou, C., Frangia, C. and Demopoulos, C.A. (2009) The Implication of Platelet Activating Factor in Cancer Growth and Metastasis: Potent Beneficial Role of PAF Inhibitors and Antioxidants. Infectious Disorders-Drug Targets, 9, 390-399. https://doi.org/10.2174/187152609788922555

[17] Ames, B.N. (1983) Dietary Carcinogens and Anticarcinogens: Oxygen Radicals and Degenerative Diseases. Science, 221, 1256-1264. https://doi.org/10.1126/science.6351251

[18] Rose, G., Blackburn, H., Keys, A., et al. (1974) Colon Cancer and Blood-Cholesterol. The Lancet, 303, 181-183. https://doi.org/10.1016/S0140-6736(74)92492-1

[19] Kark, J.D., Smith, A.H. and Hames, C.G. (1980) The Relationship of Serum Cholesterol to the Incidence of Cancer in Evans County, Georgia. Journal of Chronic Diseases, 33, 311-332.

[20] Chyou, P.H., Nomura, A.M., Stemmermann, G.N. and Kato, I. (1992) Prospective Study of Serum Cholesterol and Site-Specific Cancers. Journal of Clinical Epidemiology, 45, 287-292. https://doi.org/10.1016/0895-4356(92)90089-6

[21] Omoti, C.E. and Idogun, E.S. (2009) Serum Lipid and Lipoprotein Profile in Nigerian Patients with Hematological Malignancies. International Journal of Health Research, 2, 267-272.

[22] Shor, R., Wainstein, J., Oz, D., Boaz, M., Matas, Z., Fux, A. and Halabe, A. (2007) Low Serum LDL Cholesterol Levels and the Risk of Fever, Sepsis, and Malignancy. Annals of Clinical \& Laboratory Science, 37, 343-348. 
[23] Alexopoulos, C.G., Blastsios, B. and Avgerinos, A. (1987) Serum Lipid \& Lipoprotein Disorders in Cancer Patients. Cancer, 60, 3065-3070.

https://doi.org/10.1002/1097-0142(19871215)60:12<3065::AID-CNCR2820601234> 3.0.CO;2-Q

[24] Nydegger, U.E. and Butler, R.E. (1972) Serum Lipoprotein Levels in Patients with Cancer. Cancer Research, 32, 1756-1760.

Submit or recommend next manuscript to SCIRP and we will provide best service for you:

Accepting pre-submission inquiries through Email, Facebook, LinkedIn, Twitter, etc. A wide selection of journals (inclusive of 9 subjects, more than 200 journals)

Providing 24-hour high-quality service

User-friendly online submission system

Fair and swift peer-review system

Efficient typesetting and proofreading procedure

Display of the result of downloads and visits, as well as the number of cited articles

Maximum dissemination of your research work

Submit your manuscript at: http://papersubmission.scirp.org/

Or contact ijohns@scirp.org 